\title{
Molecular Cloning and NMR Characterization of the Nonreceptor Tyrosine Kinase PTK6 SH3-SH2-Linker Domain
}

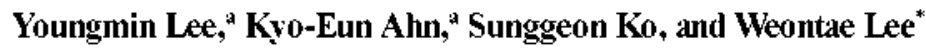 \\ Department of Biochemistry, College of Life Science \& Biotechnology, Yonsei Liniversity, Seoul 120-7+9, Korea \\ E-mail: wleeràspin vonseiac.hr \\ Received Harch 11, 2009, Accepted Ifarch 26, 2009
}

\begin{abstract}
Human protein tyrosine kinase-6 (PTK6) is a member of the non-receptor protein tyrosine kinase family and it is found in two-thirds of all breast tumors. Very recently, we proposed that the SH3 domain of PTK6 interacts with the linker region (Linker) between the SH2 and kinase domains, proving that the interaction between SH3 domain and Linker plays an important role in auto-inhibition mechanism. Residues from 1 to 191 corresponding region of SH3-SH2-Linker (SH32L) of PTK6 was cloned into the pET32a expression vector with Tobbaco etch virus (TEV) protease enzyme site by sequence homology and 3D structural model. The purified PTK6-SH32L was determined as a monomer conformation in solution. The amide proton resonances in the ${ }^{15} \mathrm{~N}-{ }^{1} \mathrm{H} 2 \mathrm{D}-\mathrm{HSQC}$ spectrum suggest that PTK6-SH32L possesses disordered structural region of the flexible/unstructured linker region. In addition, the backbone anide proton chemical shifts of the SH3 domain in the PTK6-SH32L differ from that of the independent donain, indicating that intra-molecular interaction between SH3 and Linker in the PTK6-SH32L is present.
\end{abstract}

Key Words: PTK6. Molecular cloning. NMR spectroscopy. Domain interaction

\section{Introduction}

Protein ty rosine kinases (PTKs) have been known as important molecules in cellular proliferation. differentiation and apoptosis. ${ }^{1.2}$ They often involves in the tumorigenesis through mutation, rearrangement. or gene amplification via hyper-activation. ${ }^{3.4}$ The human PTK6, a non-receptor protein tyrosine kinase is frequently observed in breast carcinomas and colon tumors as an over-expressed form.

PTK6 is composed of Src homology 3 (SH3). Src homology 2 ( $\mathrm{SH} 2$ ). and catalytic domains and especially' the $\mathrm{SH} 2$ domain is mainly involved in negative regulation of kinase activity. ${ }^{5.7}$ Phosphorylation of a highly conserved tyrosine residue in the $\mathrm{SH} 2$ domain stabilizes an inactive conformation through its conformational change by interactions between the $\mathrm{SH} 3$ domain and a polyproline sequence near the kinase domain. Previously. we have reported that the $\mathrm{SH} 2$ domain of human PTK6 contains a consensus $\alpha / \beta$-fold with a pTy peptide binding surface, however. two of the $\alpha$-helices ( $\alpha \mathrm{A}$ and $\alpha B$ ) are located on opposite faces of the central $\beta$-sheet by NMR spectroscopy. ${ }^{8.5}$ In addition. we proposed that the $\mathrm{SH} 3$ domain of PTK6 interacts with the linker region between the SH2 and kinase domains and a Trp 44 residue in the $\mathrm{SH} 3$ domain plays a key role in the intra-molecular interaction with proline-rich linker region by data from site-directed mutagenesis and surface plasmon resonance experiments. ${ }^{10.1513}$ Since the interaction between $\mathrm{SH} 3$ domain and linker region is mainly responsible for both auto-inhibitory and substrate binding mechanism. it is of interest to characterize detailed structural information between $\mathrm{SH} 3-\mathrm{SH} 2$ domain and linker region. Here. we present the molecular cloning and NMR characterization of the SH3-SH2-linker domain (SH32L) for further structural and biochemical analysis related to auto-inhibitory mechanism of the non receptor tyrosine kinase. PTK6.

\footnotetext{
${ }^{2}$ These authors contributed equally
}

\section{Experimental Procedures}

Molecular cloning, protein expression and purification. The SH32L is cloned into pET32a vector with Tobbaco etch virus (TEV) protease enzyme site, the Histidine(His) tag and thioredoxin(Trx) tag(Novagen) on $\mathrm{N}$-terminal region. The transformed vector expressed fusion protein which was induced with $0.15 \mathrm{mM}$ isopropyl- $\beta$-D-thiogalactopyranoside (IPTG) at $18^{\circ} \mathrm{C}$ for $16 \mathrm{hr}$. The harvested cells were lysised in $25 \mathrm{~mL}$ of lysis buffer contaning $25 \mathrm{mM}$ sodiun phosphate. $\mathrm{pH}$ 7.4. $300 \mathrm{mM} \mathrm{NaCl}$ and $10 \mathrm{mM} \beta$-mercaptoethanol. The

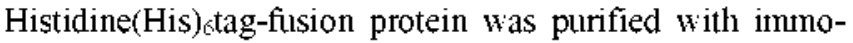
bilized metal affinity chromatography on a Ni-NTA colunn. The fusion protein was cleaved by purified TEV protease enzyme for 12 hr at $25^{\circ} \mathrm{C}$. Further purification to insure high purity was carried out by gel filtration column chromatography with HiLoad Superdex 75 prep grade column.

Isotope labeling and protein purification. A transformed cell was grown in M9 minimal medium $[0.5 \%$ (W/V) D-glucose, $0.1 \% \mathrm{NH}_{4} \mathrm{Cl} .0 .05 \% \mathrm{NaCl}, 0.6 \% \mathrm{Na}_{2} \mathrm{HPO}_{4} .1 \mathrm{mM}$ $\mathrm{MgSO}_{4}$. pH 7.4] at $37{ }^{\circ} \mathrm{C}$. One mM IPTG (isopropyl- $\beta$ D-thiogalactopyranoside) was added to the growth medium to induce protein expression after cell density reached $O D_{i j i}$ of 0.6 . Cells were harvested by centrifugation after induction. Uniformly ${ }^{13} \mathrm{C} /{ }^{15} \mathrm{~N}$ - or ${ }^{15} \mathrm{~N}$-isotopically labeled protein samples were prepared by growing cells in M9 minimal media containing ${ }^{15} \mathrm{NH}_{4} \mathrm{Cl}$. either with or without ${ }^{13} \mathrm{C}_{6}-\mathrm{D}$-glucose as the sole source of nitrogen and carbon. The cell pellets were suspended in phosphate-buffered saline $(\mathrm{pH} 7.0)$ that contained $7 \mathrm{mM}$ EDTA and $0.01 \mathrm{mM}$ PMSF, and the cells were sonicated. The PTK6 \$H3 domain fused to GST was also purified with Glutathion Sepharose 4B (Amersham Pharmacia Biotech. Uppsala. Sweden) and was subjected to digestion with bovine thrombin (Amersham Pharmacia Biotech. Uppsala. Sweden) for $5 \mathrm{~h}$ to remove GST tag. Further 
purification was accomplished using fast performance liquid chromatography (FPLC) with Superdex 75 HR 10/30 column in $50 \mathrm{mM}$ potassium phosphate buffer at $\mathrm{pH} 7.0$. The NMR protein samples for NMR measurement were approximately $1 \mathrm{mM}$ concentration in $90 \% \mathrm{H}_{2} \mathrm{O} / 10 \%{ }^{-} \mathrm{H}_{2} \mathrm{O}$ and placed in a $5 \mathrm{~mm}$ symmetrical micro cell (Shigemi. Tokyo. Japan).

NMR spectroscopy. All NMR experiments were performed at $298 \mathrm{~K}$ on a Bruker DRX500 spectrometer equipped with a cryo-probe head and shielded triple-axis gradients coil. The ${ }^{1} \mathrm{H}$ chemical shifts were referenced to intemal sodium $4.4-$ dimetlyyl-4-silapentane-1-sulfonate (DSS). The "N chemical shifts were referenced indirectly using the ${ }^{\mathrm{l}} \mathrm{H} / \mathrm{X}$ frequency ratios of the zero-point: $0.101329118\left({ }^{15} \mathrm{~N}\right)$. The ${ }^{1} \mathrm{H}-{ }^{15} \mathrm{~N} 2 \mathrm{D}-\mathrm{HSQC}$ experiment was acquired using a unifonly ${ }^{15} \mathrm{~N}$-labeled sample. Pulsed-field gradient (PFG) techniques with a WATERGATE pulse sequence were used for all $\mathrm{H}_{2} \mathrm{O}$ experiments. ${ }^{14.15}$ The $3 \mathrm{D}$ triple resonance experiments. HNCA. $\mathrm{HN}(\mathrm{CO}) \mathrm{CA}$. $\mathrm{HNCACB}, \mathrm{CBCA}(\mathrm{CO}) \mathrm{NH}^{16}$ were collected for backbone resonance assignment. All NMR data were processed on a Silicon Graphics Indigo" workstation using numrPipe/nmmDraw software (Biosy m/Molecular Simulations, Inc.). Sparky $3.95^{17.18}$ and XEASY programs ${ }^{19.0}$ were used for spectral analysis.

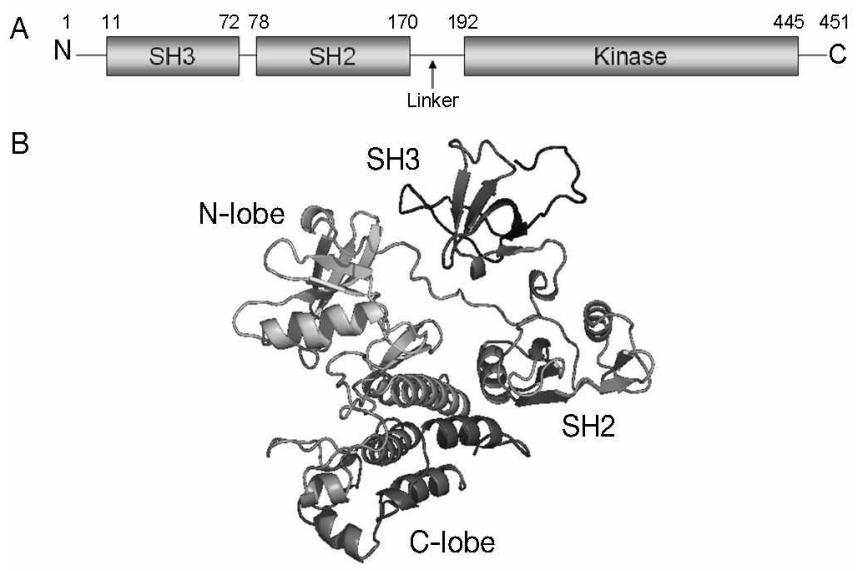

C

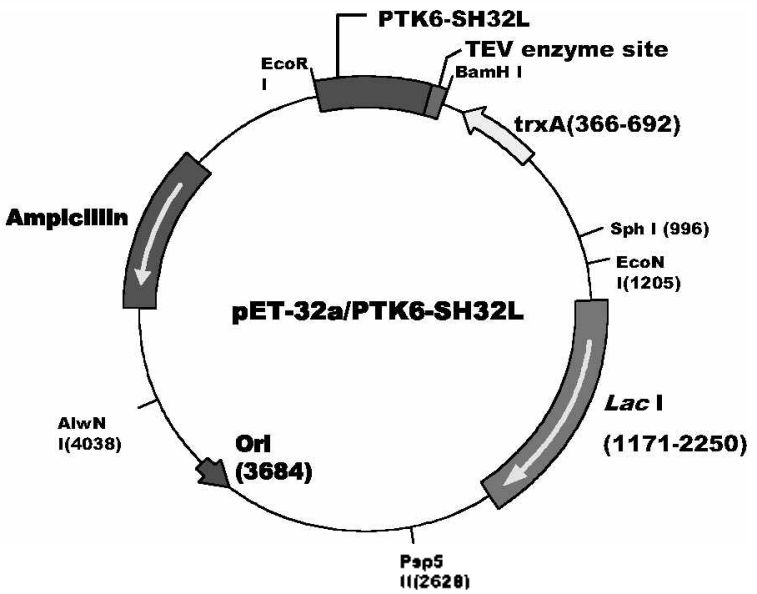

Figure 1. Domain construction, three-dimensional model and vector map of PTK6. (A) Structural domains with sequence intomation are detemined by structural analysis. (B) Three-dimensional model of the PTK6 generated by homology modeling shows domain interactions. (C) The map of Eccoli expression vectors containing PTK6 SH32L is presented.

\section{Results and Discussion}

Molecular cloning and puification of PTK6 SH32L. Figure 1 A shows donain organization of PTK6, which consists of SH3. SH2. Linker and kinase domains. Residues from I to 191 corresponding region of $\mathrm{SH} 3-\mathrm{SH} 2$-linker (SH32L) of PTK6 for cloning was determined by data from sequence homology and 3D structural model (Fig. 1B). PTK6 SH23L was successfully cloned into the pET32a expression vector with Tobbaco etch virus (TEV) protease enzyme site (Fig. 1C). The PTK6 SH32L was purified as a purity of $>95 \%$ determined by SDS-PAGE (Fig. 2A) and NMR spectrum. From our previous studies. we examined that the Linker region could contribute the protein solubility even though it is highly flexible. To determine the oligomeric state of PTK6 SH32L. size exclusion cluromatography experiment was perfomed using Superde. ${ }^{\text {TM }} 75$. Four proteins which are albumin(66 KDa). carbonic andydrase $(29 \mathrm{KDa})$, cytochrome C (12 $\mathrm{KDa})$ and aprobinin $(6.5 \mathrm{KDa})$. were used as standard molecular weight and the actual molecular weight of PTK6 SH23L was calculated by progran Origin 7.1 (Fig. 2B). The purified PTK6 SH32L was detennined as a monomer conformation in solution (Fig. 2B).
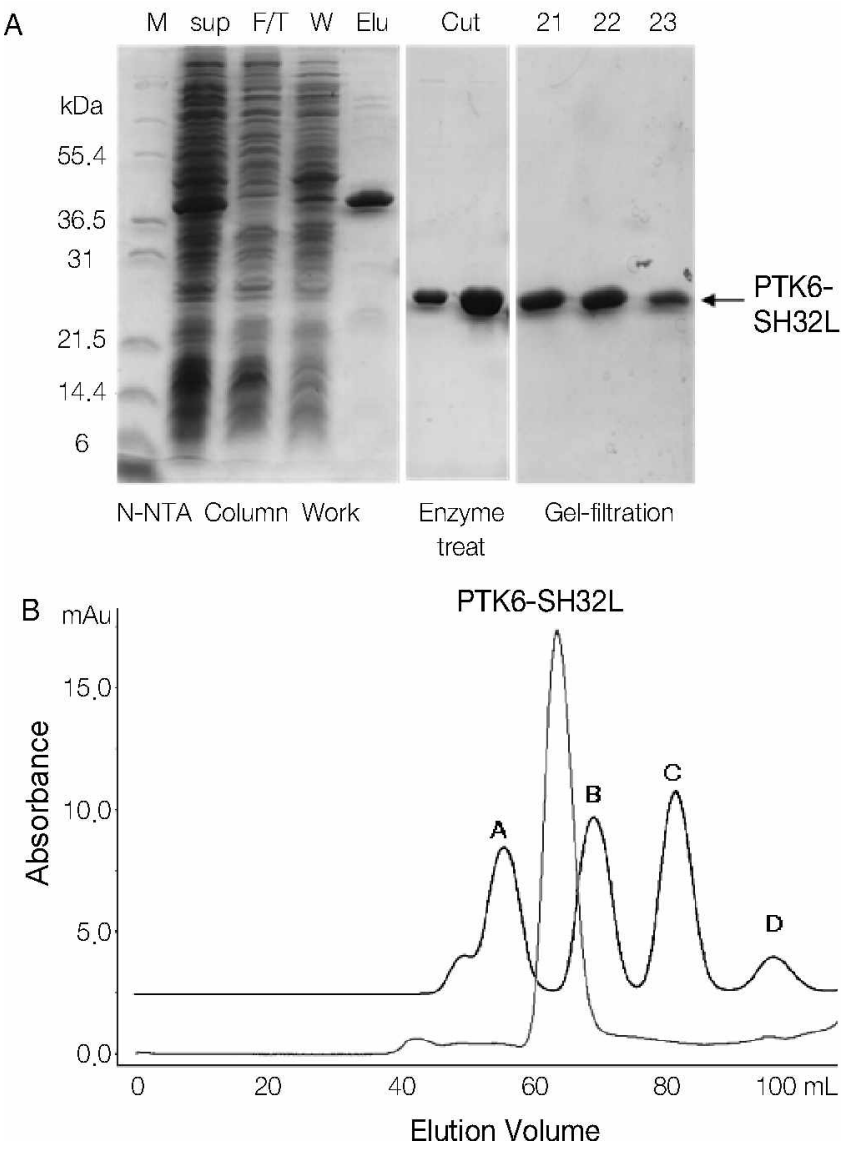

Figure 2. The SDS pages showing solubility and purification of the PTK6 SH32L. (A) SH32L proteins were identified by 15\% SDSPAGE and the molecular weight was measured using molecular size marker, Mark 12 (Invitrogen Co.) and gel filtration chromatography. (B) Elution profile of the size exclusion chromatography. The standard marker proteins were loaded and analyzed by Origin 7.01 (Origin Lab.). 
A
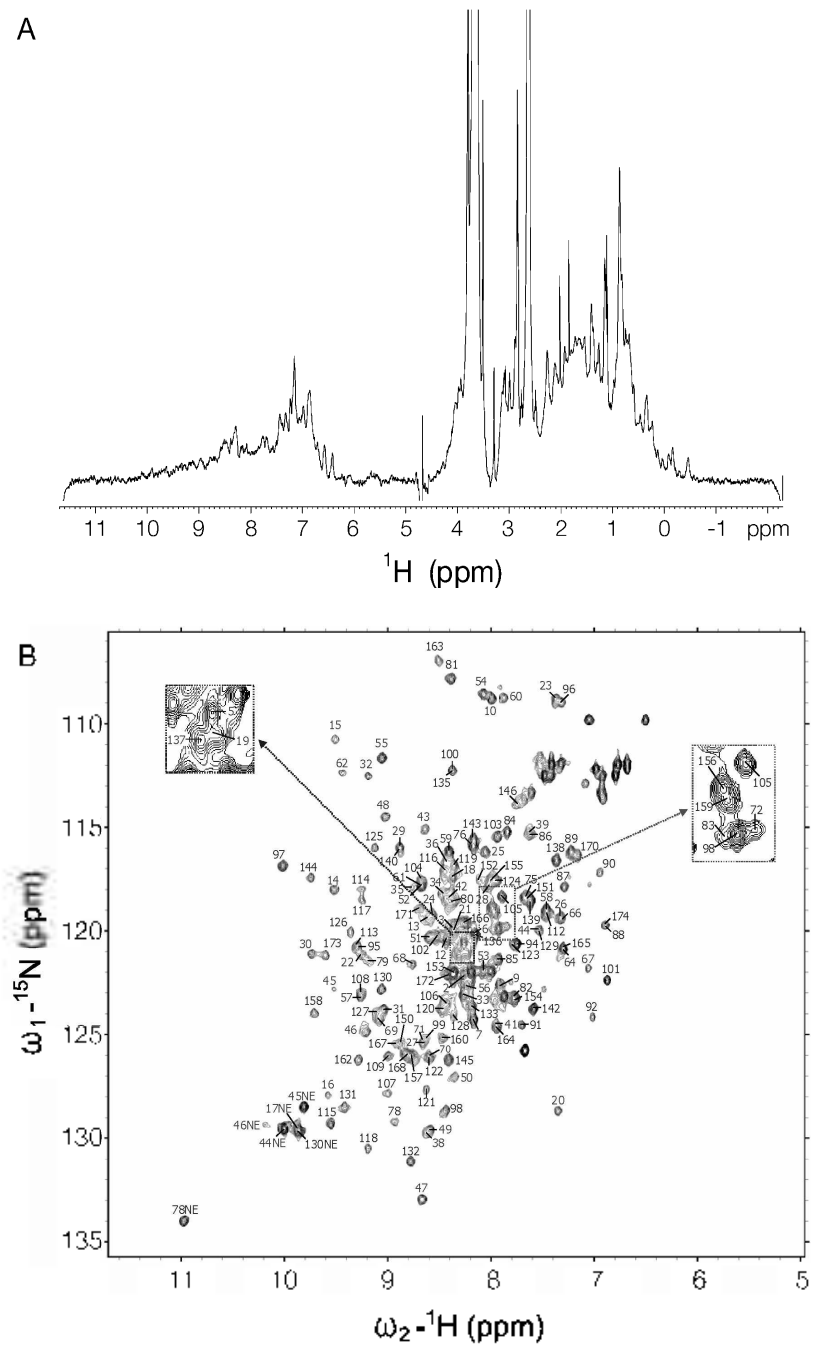

Figure 3. One-dimensional proton and ${ }^{1} \mathrm{H}-{ }^{15} \mathrm{~N} 2 \mathrm{D} \mathrm{HSOC}$ spectra of Pl'K6 SII32I. (A) One-dimensional 'II NMR spectrum of the PIIK6 SI $132 \mathrm{~L}$ in $90 \% \mathrm{I1}, 0 / 10 \%{ }^{2} 1 \mathrm{l}_{2} \mathrm{O}$ solution al pI $7.0,25{ }^{\circ} \mathrm{C}$. Presaturation of water was applicd to minimisc water signal. (B) ${ }^{1} \mathrm{H}^{15}{ }^{14} \mathrm{~N} 2 \mathrm{D}-\mathrm{HSOC}$ spectra of the PTK6 SH32L are displayed. The backbone resonance assignment of PTK6-SH32 L is presented. The resonances of the $S 133$ and $S I I 2$ domain are indicaled by navy blue and brown colors, respectively. NMR experiments were performed in Bruker DRX $500 \mathrm{MHz}$ spectrometer equipped with Cryoprobe ${ }^{\mathrm{TM}}$

NMR characterization of the PTK6 SH23L. Figure $3 \Lambda$ shows one-dimensional 'H I NMR spectrum of PTK6 \$1 13 in $90 \% \mathrm{H}_{2} \mathrm{O} / 10 \%{ }^{2} \mathrm{H}_{2} \mathrm{O}$ solution at $\mathrm{pH} 7.0$. A number of high-ficld shifted methyl proton resonances from $0.5101 .0 \mathrm{ppm}$ and amide proton resonances $(7.5-9.5 \mathrm{ppm})$ strongly suggest that the PTK6-SI I32L has a stable tertiary structure in our experimental condition. $\left.{ }^{15} \mathrm{~N}-{ }^{1} \mathrm{H} 2 \mathrm{I}\right)-\mathrm{HSQC}$ spectrum collected al $\mathrm{pH}$ 7.0 also implies that $P^{\prime} \mathrm{K} 6 \mathrm{KH} 32 \mathrm{l}$. has a unique folded conformation based on a number of cross peaks at low field region. The backbone resonance assignments of the $\mathrm{SH} 32 \mathrm{~L}$, has been performed by data tirom IINCACB, CBCA(CO)NH. IINCO and $\mathrm{HCACO}$ spectra. The results from backbone assignment are summarized in $\mathrm{Fig}$. 3B. The resonances of the $\$ 113$ and SII2 domain are indicated by navy blue and brown colors. respectively.

Struchural and functional implication. The line widths of the amide proton resonances near $8.3 \mathrm{ppm}$ in the ${ }^{15} \mathrm{~N}-{ }_{-1} \mathrm{H} 2 \mathrm{D}$ IISQC spectrum suggest that PTK'6 SH132L, might possess unstructured region at this experimental condition (Fig. 3B). This might be due to flexible/unstructured structure of the Linker region. In addition, a number of backbone amide proton resonances of both $\mathrm{SH} 3$ and $\mathrm{SH} 2$ domain in the $\mathrm{SH} 32 \mathrm{I}$. dilfer from those of the free forms. ${ }^{16.11}$ This could be easily explainable from intra-molecular interaction between each domain in the SH32L. For instance, we have previously shown that the residues in the $\$ 13$ domain interact with those in the Linker region. resulting auto-inhibition of the P'JK6 activity. . $^{2,15}$ Since the biological role of the SI 132L of PTK6 is still unclear despite the structural homology with those of other family proteins, three-dimensional structural information together with hiological data would be of importance in understanding the molecular function of PTK6. Therefore, our report lirom this study will contribute for detailed structure-functional investigation of the $\mathrm{SH} 32 \mathrm{~L}$ domain and multi-dimensional VMR experiments to determine the detailed three-dimensional structure of the $\mathrm{SH} 32 \mathrm{I}$. are currently in progress.

\section{Conclusion}

lluman protein tyrosine kinase-6 (PTK6) found in twothirds of all breast tumors has been an excellent target for drug development. Recently, we have shown that the interaction hetween SII3 domain and linker region plays an important role in auto-inhibition mechanism. In this report, residues from 1 to 191 corresponding region of SI I3-SE [2-linker (SI [32L) was cloned and purilied as a monomer conformation in solution. NMR data reveals that the PTK6-S1 132L possesses unstructured region due to the flexible/unstructured region of the Linker. The intra-molecular interaction between $\mathrm{SH} 3$ domain and Linker region is clearly observed in the "V-'I] 2D-F ISQC spectra of P'TK6-SH32I.

Acknowledgments. This work was supported by a grant (No. 070292) firom National R\&D program for Cancer Control litom the Ministry of I lealth \& Welfare. This work was also supported in part by the Brain Korea 21 Project.

\section{References}

I. Barker. K. T.: Jackson, L. E.; Crompton, M. R. Oncogene 1997. I5, 799-805

2. lee. S. T': Strunk. K. M.: Sprit\%. R. A. Oncogene 1993, 8, 3403-3410

3. Witchell, P. I. Sara, E. A.: Crompton, M. R. Oncogene 2000, 19. 4273-4282.

4. Mitchell, P. I.: Barker, K. T.: Martindale, J. I:.: Kamalati. I.: lowe, P. N.: Page, M J.: Gusterson, 13. A.: Crompton, M. R. Oncogene 1994, 9, 2383-2390

5. Kamalati, T.: Jolin, H. E.: Fry, M. J.: Crompton, M. R. Oncogene 2000, 19,5471-5476.

6. Qiu. II.: Miller, W. T'. Oncogene 2004, 23, 2216-2223,

7. Oiu, H.: Todd Millcr, W. Jom of Biological Chemistry 2002. $277,34634-34641$

8. Ierry, J. J.: Prins, G. S.: Ray, V.: Tyner. A. 1.. Oncogene 2003. $22,4212-4220$

9. Lec, H.: Kim, M.: Lec, K. H.: Kang, K. N.: Lee, S. T. Holecutes and Cells 1998, 8,40I-407.

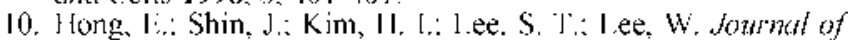
Biological Chemisto 2004, 279. 29700-29708 
11. Hong, E.: Shin, T: Bang, E.; Kim, M. H.: Lee, S. T.; Lee, W. Joumal of Bionolectlar M RR 2001, 19, 291-292.

12. Kim, H. I.; Lee, S. T. Jommal of Biological Chemistry 2005 , $280,28973-28980$.

13. Kim, H. I. Tung, T; Lee, E. S.; Kim, Y. C.; Lee, W.; Lee, S. T. Biochemical and Biophnsical Research Commmications 2007, $362,829-834$

14. Bartels, C.; Xia, T. H.: Billeter, M.: Güntert, P: Wüthrich, K.

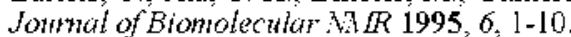

15. Piotto, M.: Sandek, V.; Sklen, V. Jommal of Biomolectlar in $R$ $1992,2,661-665$.
16. Davis, A. L.; Keeler, J.; Laue, E. D.; Moskau, D. Joumal of Magnetic Resonance (1969) 1992, 98, 207-216.

17. Lippens, G.; Dhallum, C.: Wierniszeski, J. M. Jommal of Biomolectilar $M I R$ 1995, 5, 327-331

18. Kay, L. E.; Xu, G. Y.; Singer, A. U: Muhandiram, D. R.; Fonmankay, I. D. Jommal of Magnetic Resonance, Sentes $B$ 1993, $101,333-337$.

19. Wüthrich, K; Billeter, M.; Braun, W. Jommal of Molecular Biology 1983, 169, 949-961.

20. Bartels, C.; Güntert, P.; Billeter, M.; Wüthrich, K. Jommal of Computational Chemistry 1997, 18, 139-149. 